\title{
Celibat duchownych - normy prawne, jego motywacje i praktyka w Kościele galijskim od połowy IV do połowy VI wieku w świetle kanonów synodów kościelnych
}

\section{Kontekst historyczno-prawny}

Zanim kwestia celibatu duchownych pojawiła się w kanonach synodów galijskich, to w Kościele katolickim od początku kształtował się zwyczaj, aby duchowni nie zawierali powtórnego małżeństwa, oraz praktyka dobrowolnego celibatu ${ }^{2} \mathrm{w}$ ścisłym sensie, to znaczy rozumianego jako bezżeństwo. Sprzyjała temu nauka wynikająca z Pisma Świętego. Chociaż kapłani starotestamentalni nie byli zobowiązani do celibatu, ale tylko do czasowej wstrzemięźliwości podczas służby Bożej w świątyni, to jednak w uzasadnieniu celibatu kapłańskiego z tekstów Starego Testamentu przytaczano bardzo często przede wszystkim teksty z Księgi Kapłańskiej. Wśród nich należy przytoczyć tekst dotyczący świętości w ogóle (,Świętymi bądźcie, ponieważ ja Bóg wasz jestem święty" - Kpł 11,44; 19,2; 20,8) oraz teksty dotyczące świętości kapłanów.

1 Dr hab. Tadeusz Kołosowski, prof. UKSW, Katedra Historii Starożytnej Instytutu Historii na Wydziale Nauk Historycznych Uniwersytetu Kardynała Stefana Wyszyńskiego; e-mail: tadekolo@kn.onet.pl; ORCID: 0000-0002-4019-3447.

2 Por. H. Stawniak, Celibat diakonów i prezbiterów $w$ dyscyplinie Kościoła łacińskiego, ,Seminare” 29 (2011) s. 47. 
Szczególnie powoływano się na Kpł 21,1-24³. Także Nowy Testament zawiera zachętę do przyjmowania „daru bezżenności” ze względu na pragnienie niepodzielnego zaangażowania się w sprawy Pana (1Kor 7) i ze względu na królestwo niebieskie (Mt 19,12) ${ }^{4}$.

Historia trzech pierwszych stuleci ujawnia, że wielu biskupów, prezbiterów i diakonów było bezżennych, ale żonaci duchowni nie mieli żadnych przeszkód w wypełnianiu swoich obowiązków ${ }^{5}$. Jednak w Kościele starożytnym coraz bardziej kształtowała się dyscyplina celibatu. W pierwszym etapie pod wpływem Pawła Apostoła (por. 1Tm 3,2; 3,12; Tt 1,6) odmawiano święceń kapłańskich mężczyznom rozwiedzionym lub ożenionym powtórnie po śmierci pierwszej żony (tzn. digamia sukcesywna) oraz nie pozwalano diakonom, prezbiterom czy biskupom na powtórne małżeństwo po śmierci żon ${ }^{6}$. Owdowiały członek stanu duchownego nie mógł się powtórnie ożenić i nie można było temu, kto powtórnie zawarł związek małżeński, udzielić święceń. Wreszcie od początku IV wieku prawo kościelne zaczyna zobowiązywać żonatych duchownych od diakona wzwyż, by od momentu święceń żyli we wstrzemięźliwości seksualnej z żoną ${ }^{7}$.

Takie prawo uchwalono na hiszpańskim synodzie w Elwirze około 306 roku $^{8}$. Kanon nr 33 dotyczący celibatu duchowieństwa w przekładzie ks. Janusza Lewandowicza brzmi następująco:

3 Por. S. Longosz, Patrystyczna motywacja celibatu kapłańskiego, VoxP 24-29 (1993-1995) s. 296-297.

4 Por. R. Pindel, Wymowa nowotestamentowych tekstów o stanie cywilnym pasterzy Kościoła, w: Stosowność celibatu w relacji do kapłaństwa, red. H. Sławiński, Kraków 2012, s. 101.

5 Por. Stawniak, Celibat diakonów i prezbiterów w dyscyplinie Kościoła łacińskiego, s. 48 .

6 Por. D. Kasprzak, Rozwój i motywacja kościelnej doktryny o celibacie duchownych (IV-VII w.), w: Stosowność celibatu w relacji do kaptaństwa, red. H. Sławiński, Kraków 2012, s. 106-107.

7 Kasprzak, Rozwój i motywacja kościelnej doktryny o celibacie duchownych, s. 107.

8 Por. S. Heid, Celibat w kościele pierwotnym. Początki obowiązku wstrzemięźliwości dla duchownych na Wschodzie i na Zachodzie, tł. S. Stańczyk, Tuchów 2000, s. 103. 
Przyjęto całkowity zakaz obejmujący biskupów, prezbiterów i diakonów, a w każdym razie wszystkich tych duchownych po wprowadzeniu na urząd: powstrzymania się od współżycia ze swymi żonami i płodzenia dzieci. Kto by tak jednak czynił, ma być pozbawiony godności duchownego?

Ten kanon, w którym całkowicie zabroniono tym duchownym pożycia małżeńskiego podczas sprawowania przez nich urzędu, był różnie interpretowany, a pewna grupa badaczy odmawia mu autentyczności i uznaje za późniejszą kompilację. Temat niniejszego artykułu nie pozwala jednak na szersze rozwinięcie tej kwestii ${ }^{10}$. Odnosząc się do powyżej zacytowanej treści tego kanonu, należy powiedzieć, że nie zabraniał on jeszcze duchownym od diakona wzwyż zawierania małżeństwa, ale jedynie zakazywał im całkowicie współżycia z żonami ${ }^{11}$ pod groźbą kary usunięcia ze stanu duchownego ${ }^{12}$. Do celibatu wstrzemięźliwości nakłaniano następnie duchownych na całym Zachodzie na podstawie dekretałów papieskich ${ }^{13}$. Chodzi przede wszystkim o papieży Syrycjusza (384-399) i Innocentego I (402-417) ${ }^{14}$, jakkolwiek nieco wcześniej papieżowi Damazemu (366-384) przypisywano dekretał Dominus Inter, który pochodzi przypuszczalnie dopiero od jego następców: Syrycjusza, względnie Innocentego ${ }^{15}$. Papież Leon Wielki (440-461) rozciągnął ten obowiązek również na subdiakonów ${ }^{16}$.

9 J. Lewandowicz, O brzmieniu i thumaczeniu kanonu 33. synodu w Elwirze-najstarszego oficjalnego tekstu Kościoła o celibacie duchowieństwa, VoxP 60 (2013) s. 218.

10 Szerzej na ten temat, zob. Heid, Celibat w kościele pierwotnym, s. 99-104; Lewandowicz, O brzmieniu i tłumaczeniu kanonu 33. synodu w Elwirze, s. 209-219.

11 Por. Longosz, Patrystyczna motywacja celibatu kapłańskiego, s. 287-288.

12 Por. Heid, Celibat w kościele pierwotnym, s. 100-101; Stawniak, Celibat diakonów i prezbiterów w dyscyplinie Kościoła łacińskiego, s. 48; D. Kasprzak, Rozwój i motywacja kościelnej doktryny o celibacie duchownych, s. 108.

13 Por. M.G. Bianco, Celibato del clero, DPAC II 641.

14 Por. Kasprzak, Rozwój i motywacja kościelnej doktryny o celibacie duchownych, s. 108.

15 Heid, Celibat w kościele pierwotnym, s. 206.

16 Por. Longosz, Patrystyczna motywacja celibatu kapłańskiego, s. 291-292. 


\section{Kanony synodów galijskich w kwestii celibatu duchownych}

Jaki oddźwięk w dyscyplinie Kościoła znalazła ukształtowana przez kanon nr 33 synodu w Elwirze i dekretały papieskie kanoniczna norma celibatu wstrzemięźliwości? W jaki sposób Kościół zachodni w uchwalonych kanonach synodalnych uzasadniał dyscyplinę celibatu i jak duchowni wyższych stopni w świetle uchwalonych na synodach kanonów realizowali ją w swoim życiu? Dobrym źródłem, którego analiza pozwoli udzielić odpowiedzi na tak postawione pytania, są kanony uchwalane na synodach kościelnych. Wybrano synody galijskie od połowy IV do połowy VI wieku.

Nie licząc niepewnego kanonu nr 25 przypisywanego synodowi w Arles (314) ${ }^{17}$, kwestię celibatu na synodach galijskich podjęto po raz pierwszy na synodzie w Valence d'Agen (374). Synod ten zakazywał udzielać święceń drugi raz żonatym lub będącym drugimi mężami swoich żon, czyli zabrania digamii ${ }^{18}$. Do tej kwestii powracają kolejne synody galijskie. Synod w Orange (441) postanawia, aby dwa razy żonaci nie osiągali godności kościelnej wyższej niż subdiakonat ${ }^{19}$. Tę samą zasadę przypomina synod w Arles zwołany po 442 roku $^{20}$. Bardziej precyzyjnie przeciw digamii występuje synod w Angres (453), który przypomina, że diakonów i prezbiterów można ustanawiać tylko spośród mężczyzn, żonatych raz, z dziewicą ${ }^{21}$. Synod w Adge (506) postanawia odnośnie do powtórnie żonatych prezbiterów i diakonów, że chociaż zachowują swoje imię prezbitera bądź diakona, to jednak prezbiterowi nie wolno celebrować Mszy Świętej, a diakonowi spełniać swej posługi22. Synod

17 „Postanowiono, że duchowny nie może się żenić z nie dziewicą, a świeckiego, który taką poślubił, nie dopuszcza się do stanu duchownego". Arelate (314), can. 25, SCL $1,74-74 *$.

18 Por. Valentia in Gallia (374), can. 1, SCL 1, 280-280*.

19 Por. Arausica (441), can. 24(25), SCL 6, 19-19*.

20 Por. Arelate (po 442), can. 45, SCL 6, 31-31*.

21 Por. Andegavium (453), can. 11, SCL 6, 187-187*.

22 Por. Agatha (506), can. 1, SCL 8, 1-1*. 
w Geronie (517) zabrania dopuszczać do duchowieństwa świeckich, którzy po żonie poznaliby inną kobietę ${ }^{23}$. Synod w Orleanie (541) przewiduje dla biskupa karę suspensy na rok, jeśliby świadomie, wbrew prawu kościelnemu podniósł do godności diakonatu lub prezbiteratu mężczyznę powtórnie żonatego albo męża wdowy. Bezprawnie ustanowieni w ten sposób diakoni lub prezbiterzy mieli być zdegradowani ${ }^{24}$. Wreszcie zakaz digamii dotyczył także wdów po prezbiterze lub diakonie. Gdyby wyszła ponownie za mąż, miała być odsunięta od wspólnoty kościelnej, dopóki nie zrezygnuje $\mathrm{z}$ zabronionego związku ${ }^{25}$.

Począwszy od synodu w Orange (441) na synodach Kościoła galijskiego zaczynają się pojawiać kanony, które wymagają od żonatych duchownych celibatu wstrzemięźliwości. Synod ten postanawia odtąd nie ustanawiać żonatych diakonów, o ile wcześniej nie zmienią sposobu życia, to znaczy nie złożą ślubu czystości ${ }^{26}$, czyli zaprzestaną współżycia z żoną. Jeśliby jakiś diakon okazał się niewstrzemięźliwy w obcowaniu ze swoją żoną, miał zostać złożony z urzędu ${ }^{27}$. Synod w Arles (po 442) powtarza ten sam wymóg względem kandydatów do diakonatu ${ }^{28}$, ale wyraźnie podobnej zmiany sposobu życia wymaga od kandydatów ad sacerdotium $^{29}$, czyli do biskupstwa i prezbiteratu. Synod w Narbonne (458) podkreśla, że prawo wstrzemięźliwości jest takie samo dla diakonów, jak i biskupów oraz prezbiterów. Wszyscy oni, jeśli dotąd byli żonaci, nie powinni opuszczać swej żony, ale małżeństwo ich z cielesnego powinno stać się duchowe, ma w nim nadal trwać miłość małżonków, a ustąpić współżycie poślubionych ${ }^{30}$. Podobnie synod w Clermont lub w Owernii (535) mówi o odrzuceniu cielesnego obcowania i zamianę wspólnego

\footnotetext{
3 Por. Gerunda (517), can. 8, SCL 8, 42-42*.

24 Por. Aurelianum IV (541), can. 10, SCL 8, 245-245*.

25 Por. Epao (517), can. 32, SCL 8, 51-51*.

26 Por. Arausica (441), can. 21(22), SCL 6, 19-19*.

27 Por. Arausica (441), can. 22(23), SCL 6, 19-19*.

28 Por. Arelate (post 442), can. 43 i 44, SCL 6, 31-31*.

29 Por. Arelate (post 442), can. 2, SCL 6, 24-24*.

30 Por. Narbonne (458/459), can. 3, SCL 6, 226-226*.
} 
pożycia na uczucie, jakie jest między rodzeństwem ${ }^{31}$. Synod w Geronie (517), przypominając jednak duchownym od biskupa aż do subdiakona, że ich żony stały się dla nich siostrami, zaleca jednak, by z nimi wspólnie nie zamieszkiwali32. Synod w Tours z 461 roku, mówiąc o karach za naruszanie prawa wstrzemięźliwości, odwołuje się do postanowienia Ojców, które w tym przypadku przewidywało odsunięcie od komunii Pańskiej ${ }^{33}$. Synod jednak postanowił złagodzić tę karę i postanowił, aby kapłani i diakoni uwikłani w małżeńską pożądliwość nie mogli awansować na wyższy stopień w hierarchii i nie sprawowali Mszy Świętej ani nie posługiwali ludowi ${ }^{34}$. Inny synod kilkadziesiąt lat później jest jednak znacznie surowszy. Jeśli jakiś duchowny narusza celibat wstrzemięźliwości, zostaje zdjęty z urzędu i odesłany do wspólnoty świeckiej. Jeśli zaś jego biskup, wiedząc o nagannym sposobie życia, pozwolił takiemu duchownemu pełnić obowiązki, to celem odbycia pokuty nie będzie mógł przez 3 miesiące sprawować swoich obowiązków ${ }^{35}$.

W aktach synodalnych Kościoła galijskiego, począwszy od synodu w Arles (po 442), zaczynają pojawiać się także szczegółowe przepisy co do zamieszkania kobiet w domu duchownego. Wspomniany synod w Arles dopuszcza, aby w domach duchownych od diakona wzwyż przebywały jedynie kobiety z nim spokrewnione. W przypadku jeśliby duchowny ośmielił się mieć w swoim domu jako pomoc inną kobietę, powinien być wyłączony z komunii Kościoła ${ }^{36}$. Również synod w Angres (453) nakazuje duchownym unikanie bliskości z obcymi kobietami i ograniczenie się tylko do towarzystwa kobiet z nimi spokrewnionych. W przeciwnym razie tacy duchowni nie powinni

\footnotetext{
31 Por. Claremontium seu Arvernia (535), can. 13, SCL 8, 158-158*.

32 Por. Gerunda (517), can. 6, SCL 8, 41-41*.

33 Użyty w tym przypadku łaciński termin communio może oznaczać zarówno wspólnotę, jak i Komunię Świętą.

34 Por. Turones (461), can. 2, SCL 6, 231-232.

35 Por. Aurelianum III (538), can. 2, SCL 8, 229-230.

36 Por. Arelate (po 442), can. 3, SCL 6, 24-24*.
} 
pełnić swojej posługi ${ }^{37}$. Synod w Tours (461) przewiduje dla takich duchownych pozbawienie komunii ${ }^{38}$, a synod w Orleanie (549) przewiduje w tym przypadku dla biskupa zdjęcie go na rok z urzędu przez metropolitę. Duchowni niżsi rangą mieli ponieść taką samą karę od swoich biskupów ${ }^{39}$. W przypadku jeśliby duchowny dopuścił się cudzołóstwa, miał być pozbawiony urzędu i odesłany do klasztoru do końca swego życia ${ }^{40}$.

\section{Synody Kościola galijskiego w kwestii motywacji celibatu duchownych}

W pismach autorów wczesnochrześcijańskich znajdujemy obszerną motywację na rzecz praktykowania przez duchownych celibatu ${ }^{41}$. Kanony synodów kościelnych z natury w sposób zwięzły stanowią normy dotyczące życia w celibacie i określają kary za ewentualne łamanie tych norm. Na ogół więc w aktach synodów kościelnych trudno znaleźć obszerniejsze uzasadnienie lub motywacje przemawiające za przyjęciem takiej czy innej normy. Przede wszystkim w aktach synodu w Tours z 461 roku można znaleźć obszerniejszą argumentację, z której można wyciągnąć jakieś treści uzasadniające i motywujące normy dotyczące celibatu duchownych. Nieco później w mniej obszerny sposób czyni to synod w Orleanie (541).

Na synodzie w Tours z 461 roku argumentacja za celibatem duchownych rozwija się wokół wstrzemięźliwości kultycznej. Wskazuje na to następujący fragment kanonu $\mathrm{nr} 1$ :

\footnotetext{
Por. Andegavium (453), can. 4, SCL 6, 186-186*.

38 Por. Turones (461), can. 3, SCL 6, 232-232*.

39 Aurelianum V (549), can. 3, SCL 8, 316-316*.

40 Por. Aurelianum III (538), can. 8, SCL 8, 232-232*.

${ }^{41}$ Wśród polskich badaczy szerzej na ten temat piszą np. S. Longosz (Patrystyczna motywacja celibatu kapłańskiego, s. 285-311) i D. Kasprzak (Rozwój i motywacja kościelnej doktryny o celibacie duchownych, s. 110-122).
} 
Gdy świeckiemu nakazuje się powściągliwość, aby mógł być wysłuchany, gdy modli się i błaga Boga, o ileż bardziej kapłani i diakoni, którzy w każdej chwili winni być gotowi dla Boga, we wszelkiej czystości i nieskazitelności, wolni od przeszkód w składaniu ofiary i udzielaniu chrztu, jeśli wymagałaby tego konieczność chwili. Gdyby splamili się cielesną pożądliwością, z jakim umysłem ${ }^{42}$ odpuszczą winy, z jaką czystością nadadzą imię, z jakim sumieniem, z jaką zasługą będą wierzyć, że są wysłuchiwani? ${ }^{43}$

Ludziom świeckim powściągliwość seksualną przed dokonywaniem aktów kultu religijnego poleca Paweł Apostoł: „Nie unikajcie jedno drugiego, chyba że na pewien czas, za obopólną zgodą, by oddać się modlitwie; potem znów wróćcie do siebie" (1Kor 7,5). Tym bardziej więc dotyczy to osób duchownych, gdy sprawują Eucharystię, udzielają innych sakramentów i wraz z ludem oddają się modlitwie. Orygenes, komentując 1Kor 7,5, stwierdza, że kapłan chrześcijański nie może w pełni oddać się modlitwie bez zachowania czystości cielesnej, ponieważ jego modlitwy kierowane do Boga nie będą czyste ${ }^{44}$. Nieprzytoczony w tym kanonie wprost tekst Pawła z 1Kor 7,5 nie jest jedynym odniesieniem do nauczania Apostoła. Można powiedzieć, że kanon nr 1 tego synodu niejako tchnie nauczaniem Apostoła zawartym w 1 Kor 7, choć bezpośrednio przytoczone są tylko słowa: „Mówię, bracia, czas jest krótki. Trzeba więc, aby ci, którzy mają żony, tak żyli, jakby byli nieżonaci” (1Kor 7,29). Cały ten kanon rozpoczyna się skierowanym do duchownych wezwaniem do świętego trybu życia i dawania wiernym dobrego przykładu. Skoro Paweł Apostoł wzywa wszystkich wiernych do przestrzegania czystości i życia według ducha, a nie według ciała (Rz 8,8-9), a więc do życia doskonałego, to tym bardziej dotyczy to duchownych. W świetle tego kanonu celibat jawi się więc jako wyraz wyższej doskonałości, do której przede wszystkim wezwany jest kapłan.

\footnotetext{
42 Łac. termin mens w tym kontekście należy raczej rozumieć jako 'stan ducha'.

43 Turones (461), can. 1, SCL 6, 231-231*.

44 Longosz, Patrystyczna motywacja celibatu kapłańskiego, s. 304.
} 
Również wstrzemięźliwością kultyczną uzasadnia się celibat wstrzemięźliwości na synodzie w Orleanie z 541 roku: „Kapłani i diakoni niech nie mają ze swoimi żonami wspólnego łoża ani pokoju, by podejrzenie obcowania cielesnego nie splamiło religii’"45. Użyty tutaj łaciński termin religio należy rozumieć w sensie 'kult, obrzęd religijny, świętość jakiejś czynności’. Synod ten motywuje więc celibat wstrzemięźliwości wstrzemięźliwością kultyczną. Tego rodzaju wstrzemięźliwość podejmowana ze względów kultycznych była już znana u kapłanów pogańskich religii świata greckiego i rzymskiego ${ }^{46}$. Autorzy wczesnochrześcijańscy, chociaż znali wstrzemięźliwość seksualną kapłanów pogańskich, to jednak uzasadnienia dla czystości rytualnej duchowieństwa chrześcijańskiego szukali przede wszystkim w Bibliii ${ }^{47}$. Synod w Orleanie nie powołuje się jednak na żadne teksty biblijne ani w żaden inny sposób nie rozwija tematu wstrzemięźliwości kultycznej.

\section{Synody Kościoła galijskiego w kwestii praktykowania celibatu przez duchownych}

Jak od strony praktycznej wyglądała realizacja dyscypliny celibatu w Kościele starożytnym? Z III i IV wieku pochodzą świadectwa, które wskazują, że nie zawsze konsekwentnie przestrzegano zakazu digamii (Hipolit Rzymski, Philosophumena 9, 12, 22; Hieronim, Ep. 69, 9) ${ }^{48}$. Około 380 roku biskup Himeriusz z Tarragony w liście do papieża Damazego pyta, jak należy postępować z duchownymi, którzy nie zachowują celibatu wstrzemięźliwości. W odpowiedzi na to pismo papież

\footnotetext{
45 Aurelianum IV (541), can. 17, SCL 8, 246-246*.

46 Por. Kasprzak, Rozwój i motywacja kościelnej doktryny o celibacie duchownych, s. 114.

${ }^{47}$ Por. Kasprzak, Rozwój i motywacja kościelnej doktryny o celibacie duchownych, s. 115.

48 Por. M.G. Bianco, Celibato del clero, DPAC II 640-641; Kasprzak, Rozwój i motywacja kościelnej doktryny o celibacie duchownych, s. 107.
} 
Syrycjusz poświadcza, że wielu kapłanów i diakonów współżyło wiele lat po swych święceniach z własnymi żonami, płodzili dzieci, a ponadto bronili swego przestępstwa, powołując się na Stary Testament, gdzie kapłanom i sługom (lewitom) dozwolone było płodzenie dzieci ${ }^{49}$.

Czy treść kanonów synodów galijskich pozwala nam na wyciągnięcie jakichś wniosków w tym względzie? Już synod w Valence d’Agen (374) przyznaje, że zbyt późno podejmuje środki zaradcze w sprawie niedozwolonej praktyki udzielania święceń powtórnie żonatym lub będących drugimi mężami swych żon. Sprawa musiała być dość poważna, skoro synod stwierdza, że nie jest w stanie naprawić istniejącej sytuacji i nie będzie dalej zajmował się już wyświęconymi w taki sposób, jeśli nie zachodzi żaden inny powód potwierdzający, że są niegodni pełnienia posługi $^{50}$. Trudno przypuszczać, że sytuacja w tym względzie uległa jakiejś poprawie skoro w 517 roku synod obradujący w Epaon miał dokładnie taki sam problem. Synod ten po przypomnieniu, aby nie ustanawiać prezbiterem ani diakonem digamisty dodaje, że: ,[...] zupełnie wystarcza to, co ustanowił Apostoł. Lecz ponieważ dowiedzieliśmy się, że tenże nakaz przekracza się z powodu prostoty niektórych braci, odnawiamy go, szczególnie jego przestrzeganie" ${ }^{\prime 51}$.

Kanony synodów w Galii pozwalają także poznać niedomagania w zakresie zachowania celibatu wstrzemięźliwości. Synod w Clermont lub w Owernii (535) w kanonie nr 13 w następujący sposób piętnuje występek (crimen) duchownych, którzy po przyjęciu święceń kontynuowali pożycie małżeńskie: „Przekonaliśmy się, że niektórzy rozpaleni żarem pożądania, porzuciwszy posterunek, powrócili do poprzednich wymiocin i zabronionych małżeństw, znieważyli kapłaństwo występkiem w pewnym sensie kazirodztwa, co zdradziły także narodzone dzieci”"52. Ten sam synod poświadcza także, że duchowni z naganną

\footnotetext{
49 Por. Ep. 1, 8, cyt. za: Heid, Celibat w kościele pierwotnym, s. 200.

50 Por. Valentia in Gallia (374), can. 1, SCL 1, 280-280*.

51 Epao (517), can. 2, SCL 8, 45-45*.

52 Claremontium seu Arvernia (535), can. 13, SCL 8, 158-158*.
} 
swobodą traktowali także przepisy Kościoła co do kwestii zamieszkiwania kobiet w ich domach. Świadczą o tym następujące słowa kanonu nr 16: „Gdyby ktoś niepamiętny przykazań Bożych uważał, że trzeba to zlekceważyć, niech wie, że autorytetem kanonów bez wątpienia podlega utracie komunii" ${ }^{53}$. W tym samym kanonie wskazuje się także na naganną postawę biskupów, którzy nie reagowali we właściwy sposób na łamanie w tym względzie dyscypliny kościelnej ze strony ich podwładnych: „Gdyby zwierzchnik kościelny nie chciał z surowością kanonów pohamować tej winy w swym prezbiterze i diakonie, sam niech będzie ukarany surowym wyrokiem" 54 . Podobne świadectwa znajdują się w uchwałach innych synodów galijskich ${ }^{55}$.

\section{Podsumowanie}

W Kościele starożytnym na początku celibat rozumiany jako bezżeństwo był dobrowolny. Bez ograniczeń święcono raz żonatych mężczyzn. Od połowy III wieku zabraniano mężczyznom nieżonatym w chwili święceń zawierania małżeństwa po ich przyjęciu. Od IV wieku powstało formalne prawo celibatu $\mathrm{w}$ sensie wymagania całkowitej wstrzemięźliwości seksualnej w relacjach z żoną. Te normy potwierdzają liczne synody kościelne w Galii i przypominają o obowiązku ich przestrzegania. Celibat wstrzemięźliwości motywowany jest głównie wstrzemięźliwością kultową, a także nauczaniem ewangelicznym i św. Pawła Apostoła. Za nieprzestrzeganie tych norm groziły różne kary kościelne, jakimi najczęściej były złożenie z urzędu i pozbawienie komunii. Treść wielu kanonów wskazuje jednak, że pomimo grożących kar praktykowanie życia w celibacie pozostawiało wiele do życzenia.

53 Claremontium seu Arvernia (535), can. 16, SCL 8, 159-159*.

54 Claremontium seu Arvernia (535), can. 16, SCL 8, 159-159*.

55 Por. Andegavium (453), can. 4, SCL 6, 186-186*; Turones (461), can 3, SCL 6, 232-232*; Aurelianum III (538), can. 4, SCL 8, 230-230*. 


\section{The Celibacy of Clergymen - Legal Norms, its Motivations and the Practice in the Gallic Church from the Half of Fourth to Half of Sixth Century in the Light of Church-Synods Canons}

(summary)

In the ancient Church at the beginning the celibacy understood as single state was free-will. To the state of the clergyman were admitted once married men. From the half of third century unmarried men after ordination they could not marry. From fourth century was the formal law of the celibacy in the meaning of the requirement of the entire sexual abstinence in relations with the wife. These legal norms confirm numerous synods in Gaul and they remind about the duty of their observance. The celibacy abstinence is motivated mainly a cult continence and also evangelical and St. Paul the Apostle teaching. For the inobservance of these norms threaten different penalties, especially deprival and the excommunication.

Keywords: celibacy; clergy; Gaul IV-VI century; church-synods

\section{Celibat duchownych - normy prawne, jego motywacje i praktyka w Kościele galijskim od połowy IV do połowy VI wieku w świetle kanonów synodów kościelnych}

(streszczenie)

W Kościele starożytnym na początku celibat rozumiany jako bezżeństwo był dobrowolny. Bez ograniczeń święcono raz żonatych mężczyzn. Od połowy III wieku zabraniano mężczyznom nieżonatym w chwili święceń zawierania małżeństwa po ich przyjęciu. Od IV wieku powstało formalne prawo celibatu w sensie wymagania całkowitej wstrzemięźliwości seksualnej w relacjach z żoną. Te normy prawne potwierdzają liczne synody kościelne w Galii i przypominają o obowiązku ich przestrzegania. Celibat wstrzemięźliwości jest motywowany głównie wstrzemięźliwością kultową, a także nauczaniem ewangelicznym i św. Pawła Apostoła. Za nieprzestrzeganie tych norm groziły różne kary kościelne, jakimi najczęściej były złożenie z urzędu i pozbawienie komunii.

Słowa kluczowe: celibat; duchowieństwo; Galia IV-VI wiek; synody kościelne

\section{Bibliografia \\ Źródła}

Dokumenty synodów od 50 do 381 roku, opr. A. Baron - H. Pietras, Synody i Kolekcje Praw 1, ŹMT 37, Kraków 2006.

Dokumenty synodów od 431 do 504 roku, opr. A. Baron - H. Pietras, Synody i Kolekcje Praw 6, ŹMT 62, Kraków 2011. 
Dokumenty synodów od 506 do 553 roku, opr. A. Baron - H. Pietras, Synody i Kolekcje Praw 8, ŹMT 73, Kraków 2014.

\section{Opracowania}

Bianco M.G., Celibato del clero, DPAC II 640-642.

Heid S., Celibat w kościele pierwotnym. Początki obowiązku wstrzemięźliwości dla duchownych na Wschodzie i na Zachodzie, tł. S. Stańczyk, Tuchów 2000.

Kasprzak D., Rozwój i motywacja kościelnej doktryny o celibacie duchownych (IV-VII w.), w: Stosowność celibatu w relacji do kapłaństwa, red. H. Sławiński, Kraków 2012, s. 105-123.

Lewandowicz J., O brzmieniu i ttumaczeniu kanonu 33. synodu w Elwirze-najstarszego oficjalnego tekstu Kościoła o celibacie duchowieństwa, VoxP 60 (2013) s. 209-219.

Longosz S., Patrystyczna motywacja celibatu kapłańskiego, VoxP 24-29 (1993-1995) s. 285-311.

Pindel R., Wymowa nowotestamentowych tekstów o stanie cywilnym pasterzy Kościoła, w: Stosowność celibatu w relacji do kapłaństwa, red. H. Sławiński, Kraków 2012, s. 77-101.

Stawniak H., Celibat diakonów i prezbiterów $w$ dyscyplinie Kościoła łacińskiego, „Seminare” 29 (2011) s. 47-59. 